\title{
Three-dimensional tomographic reconstruction and morphometric analysis of skull in gazelles (Gazella subgutturosa)
}

\author{
Bestami YILMAZ ${ }^{1, \mathrm{a}, \bowtie}$, İsmail DEMİRCİOGLUU ${ }^{1, \mathrm{~b}}$, Faruk BOZKAYA $^{2, \mathrm{c}}$, Nazan GEZER İNCE $^{3, \mathrm{~d}}$ \\ ${ }^{1}$ Harran University, Faculty of Veterinary Medicine, Department of Anatomy, Şanlıurfa; ${ }^{2}$ Harran University, Faculty of Veterinary \\ Medicine, Department of Genetics, Şanlıurfa; ${ }^{3}$ İstanbul Cerrahpaşa University, Faculty of Veterinary Medicine, Department of \\ Anatomy, İstanbul, Turkey. \\ aORCID: 0000-0002-0901-3129, bORCID: 0000-0002-0724-3019, ' ORCID: 0000-0001-6423-8067, \\ dORCID: 0000-0003-1627-5757
}

Corresponding author: byilmaz@harran.edu.tr

Received date: 19.07.2019- Accepted date: 14.11.2019

\begin{abstract}
This study was carried out to determine the osteometric features of the skull by using three dimensional computed tomography images in gazelles (Gazelle subgutturosa). In the study, nine skull samples of adult gazelles (Gazella subgutturosa) were used. Images of the skull sections of $0.625 \mathrm{~mm}$ thickness were acquired by using a computer tomography device with 64 detectors applying $80 \mathrm{kV}, 200 \mathrm{~mA}$ and $639 \mathrm{mGY}$. Three-dimensional images of the skull samples were reconstructed and morphometric measurements (39 linear, 1 volumetric and 1 surface area) were performed by using the software program MIMICS 12.1. Mean skull volumes in males and females were found to be $115.74 \pm 2.43 \mathrm{~cm}^{3}$ and $87.69 \pm 1.09 \mathrm{~cm}^{3}$ while the mean skull surface areas in males and females were $79.62 \pm 8.56 \mathrm{~cm}^{2}$ and $77.34 \pm 1.18 \mathrm{~cm}^{2}$, respectively. Significant differences between males and females for median frontal length (MFL), frontal length (FRL), upper neurocranium length (UNCL), greatest length of the lacrimal bone (GLLB), oral palatal length (OPL), length of the upper molar row (LUMR) and the greatest neurocranium breadth (GNCB) were observed. The difference in the cranial index between males and females was statistically significant $(\mathrm{P}<0.01)$. The data obtained in this study will contribute to detect differences between the gazelles and other species with respect to skull morphometry.
\end{abstract}

Keywords: Computed tomography, gazelle, morphometry, reconstruction, skull.

\section{Ceylanlarda (Gazella subgutturosa) kafatasının üç boyutlu tomografik rekonstruksiyonu ve morfometrik analizi}

Özet: Bu çalışma; ceylan kafatasının bilgisayarlı tomografi görüntülerini kullanılarak kafatası kemiklerinin osteometrik özelliklerini belirlemek amacıyla yapılmıştır. Çalışmada 9 adet erişkin ceylan (Gazella subgutturosa) kafatası kullanıldı. Kafataslarının 64 dedektörlü CT cihazı ile $80 \mathrm{kv}, 200 \mathrm{MA}, 639 \mathrm{mGY}$ ve $0,625 \mathrm{~mm}$ kesit kalınlığında görüntüleri alındı. Bu görüntüler MIMICS 12.1 programı yardımıyla üç boyutlu yapıya dönüştürülerek morfometrik ölçümleri (39 linear, 1 hacim ve 1 yüzey alanı) yapıldı. Erkeklerde kafatasının ortalama hacim değeri 115,74 $\pm 2,43 \mathrm{~cm}^{3}$, dişilerde $87,69 \pm 1,09 \mathrm{~cm}^{3}$ olarak tespit edilirken cranium'un ortalama yüzey alanı erkeklerde $79,62 \pm 8,56 \mathrm{~cm}^{2}$, dişilerde $77,34 \pm 1,18 \mathrm{~cm}^{2}$ olarak bulundu. Çalışmada, median frontal uzunluk (MFL), frontal uzunluk (FRL), üst neurocranium uzunluğu (UNCL), lacrimal kemiğin maximum uzunluğu (GLLB), oral palatal uzunluk (OPL), üst molar diş sırası uzunluğu (LUMR) ve en büyük neurocranium genişliği (GNCB) parametrelerinde dişi ve erkekler arasındaki farklar istatistiksel olarak anlamlı bulundu. Cranial index değeri açısından dişi ve erkekler arasındaki fark istatistiksel olarak anlamlıydı $(\mathrm{P}<0,01)$. Çalışmada elde edilen bilgilerin ceylan türlerinin tipolojisi ile diğer türlerle arasındaki farklılıkların tespitine katkı sunacağı düşünülmektedir.

Anahtar sözcükler: Bilgisayarlı tomografi, ceylan, kafatası, morfometri, rekonstruksiyon.

\section{Introduction}

Even among the closely related species, there are apparent differences in the skeletal systems. These differences are crucial for taxonomic classification of species and for evaluation of the archaeological or forensic findings (26). Skull is the most studied bone for reconstructing the evolutional taxonomy. However, the assignment of the species based on skull characteristics is difficult due to variation within species (1). Knowledge of cranial morphometry is also important for the diagnosis of cranial or dental deformities for designing implants or dental instruments $(26,27)$. 
Three different techniques have been used for obtaining osteometric parameters. The first is the measurement of bones obtained from archaeological excavations or after maceration by using a compass (23). The second is the evaluation of the radiological images from the target region (16). The third one is the measurement of the images obtained by using computer tomography (CT), which is a recently more frequently used technique (27). Images of two-dimensional sections from CT are compiled to reconstruct a three dimensional (3D) image using special software programs $(10,22)$. The 3D modeling technique is widely employed in plastic surgery, orthopedic surgery, neurosurgery, traumatology and medical education (17).

Gazella is one of the most species-rich genus comprising numerous species within Bovidae (1). Gazelles in Sanliurfa belongs to Gazella subgutturosa, which has a wide distribution area ranging from China to North Africa. Since the second half of $20^{\text {th }}$ - century number of the gazelles have rapidly declined due to human activities including habitat destruction, expansion of the agricultural areas, hunting, etc. (19).

Several morphometric studies have been performed for establishing a comprehensive and reliable database in gazelles $(1,9,31)$. The objective of this study was to morphometrically analyze the skulls of gazelles by using the CT images in order to provide species specific data that can be used by veterinary clinicians for managing pathological formations on the skull.

\section{Material and Methods}

Animal material: In the study nine cadavers (5 females and 4 males) of adult gazelles were used. Body weights of the cadavers were among $11.4-18.1 \mathrm{~kg}$. The cadavers were submitted to the clinics of Harran University Animal Hospital in Sanliurfa province of Turkey for treatment yet died for various reasons. The animals had no clinical or pathological skull problems. The use of the cadavers was approved by the General Directorate of Nature Conservation and National ParksTurkey (Approval no: 2017/209842) and Harran University Animal Experimentation Local Ethics Committee (Approval no: 2018/006-11).

CT-Imaging, reconstruction and morphometric analysis: For obtaining the CT images the gazelle cadavers were placed on a sternal position into a CT device with 64 detectors (GE Company, USA) . Images of the skull sections of $0.625 \mathrm{~mm}$ thickness were acquired by applying $80 \mathrm{kV}, 200 \mathrm{~mA}$, and $639 \mathrm{mGY}$. The CT images were stored in DICOM format and the 3D skull images were reconstructed using the basic module of the $3 \mathrm{D}$ modeling program MIMICS 20.1 (The Materialise Group, Leuven, Belgium). Osteometric measurements on the digital images were performed for 39 different parameters according to the measurement points reported in the literature $(25,29)$. Definitions and the abbreviations of the studied parameters were shown in Table 1. After morphometric measurements, volume and surface area of the skulls were estimated by excluding the horns and mandible. Further 6 different indices were calculated based on the craniometric measurements (Table 2). The definitions were based on Nomina Anatomica Veterinaria (20).

Statistical analysis: All morphometric parameters were expressed as Mean \pm Standard Error (SE). The presence of significant differences between sexes was examined by using the Mann-Whitney $U$ test. For statistical analyses SPSS, 17.0 was used.

\section{Results}

In this study, 39 linear parameters of the skull were measured (Figure 1-4). The mean \pm standard error values for each parameter in males and females were shown in Table 3. Statistically significant differences $(\mathrm{P}<0.05)$ between males and females for MFL (median frontal length), FRL (frontal length), UNCL (upper neurocranium length), GLLB (greatest length of the lacrimal bone), OPL (oral palatal length), LUMR (length of the upper molar row) and GNCB (greatest neuro-cranium breadth) were observed.

Furthermore, cranial volume values in males and females were detected to be $115.74 \pm 2.43 \mathrm{~cm}^{3}$ and $87.69 \pm 1.09 \mathrm{~cm}^{3}$, respectively. The cranial surface area in males and females was $79.62 \pm 8.56 \mathrm{~cm}^{2}$ and $77.34 \pm 1.18$ $\mathrm{cm}^{2}$, respectively (Table 4). The difference in mean cranial volume between males and females was significant while there was no difference in cranial surface area between sexes. Data on the skull indices have been shown in (Table 5). A statistically significant difference between males and females was observed only for cranial index values. 
Table 1. Studied cranial parameters (according to Von den Driesch (30)).

\begin{tabular}{|c|c|c|}
\hline Parameter & Abbreviation & Definition \\
\hline 1 & TLS & Total length of the skull: the distance between akrokranion-prosthion \\
\hline 2 & CBL & Condylobasal length: caudal border of occipital condyles-prosthion \\
\hline 3 & TLCB & Total length of the cranial base: basion-prosthion \\
\hline 4 & SSL & Short skull length: basion-premolare \\
\hline 5 & PPL & Premolare-prosthion length \\
\hline 6 & NCL & Neurocranium length: basion-nasion \\
\hline 7 & ULVC & Upper length of the viscerocranium: nasion-prosthion \\
\hline 8 & MFL & Median frontal length: akrokranion-nasion \\
\hline 9 & ACBL & Akrokranion-bregma length \\
\hline 10 & FRL & Frontal length: bregma-nasion \\
\hline 11 & UNCL & Upper neurocranium length: akrokranion-supraorbitale \\
\hline 12 & FCL & Facial length: supraorbitale-prosthion \\
\hline 13 & ACIO & Akrokranion-infraorbitale length \\
\hline 14 & GLLB & Greatest length of the lacrimal bone \\
\hline 15 & GLNB & Greatest length of the nasal bone: nasion-rhinion \\
\hline 16 & EOPL & Entorbitale-prosthion length \\
\hline 17 & DOCI & Distance between the caudal border of occipital condyle and the infraorbitale \\
\hline 18 & DTL & Dental length: postdentale-prosthion \\
\hline 19 & OPL & Oral palatal length: palatinoorale-prosthion \\
\hline 20 & LLPM & Lateral length of the premaxilla: nasointermaxillare-prosthion \\
\hline 21 & LMTR & Length of the maxillary tooth row \\
\hline 22 & LUMR & Length of the upper molar row \\
\hline 23 & LUPR & Length of the upper premolar row \\
\hline 24 & GIWO & Greatest inner width of the orbit: ectorbitale-entorbitale \\
\hline 25 & GIHO & Greatest inner height of the orbit \\
\hline 26 & GMB & Greatest mastoid breadth: otion-otion \\
\hline 27 & GBOC & Greatest breadth of the occipital condyles \\
\hline 28 & GBPP & Greatest breadth at the bases of the paracondylar processes \\
\hline 29 & GBFM & Greatest breadth of the foramen magnum \\
\hline 30 & HFM & Heigth of the foramen magnum: basion-opisthion \\
\hline 31 & LBP & Least breadth of parietal \\
\hline 32 & GBLH & Greatest breadth between the lateral borders of the horncore base \\
\hline 33 & GNCB & Greatest neurocranium breadth: euryon-euryon \\
\hline 34 & GFB & Greatest frontal breadth: ectorbitale-ectorbitale \\
\hline 35 & LBO & Least breadth between the orbits: entorbitale-entorbitale \\
\hline 36 & FCB & Facial breadth: between facial tuberosities \\
\hline 37 & GBAN & Greatest breadth across the nasal bones \\
\hline 38 & GBAP & Greatest breadth across the premaxilla \\
\hline 39 & GPB & Greatest palatal breadth \\
\hline
\end{tabular}

Table 2. Indices and formulas of the skulls (According to Parés-Casanova (26)).

\begin{tabular}{|c|c|}
\hline Studied indexes & Formulas \\
\hline Skull index & greatest frontal breadth (var. 34) / total length of the skull (var. 1) ${ }^{x} 100$ \\
\hline Cranial index & greatest neurocranium breadth (var. 33) / median frontal length (var. 8) ${ }^{\times} 100$ \\
\hline For. magnum index & height of the for. magnum (var. 30) / greatest breadth of the for. magnum (var. 29) ${ }^{\mathrm{x}} 100$. \\
\hline Orbital index & orbital inner width (var. 24) / orbital inner height (var. 25) $\times 100$ \\
\hline Facial index & facial width (var. 36) / facial length (var. 12) x 100 \\
\hline Nasal index & greatest breadth across the nasals (var. 37) / greatest length of the nasals (var. 15) ${ }^{x} 100$. \\
\hline
\end{tabular}


Table 3. The mean and standard deviations of the skull measurements (mm).

\begin{tabular}{|c|c|c|c|c|c|c|c|}
\hline \multirow{2}{*}{\multicolumn{2}{|c|}{ Parameter }} & \multicolumn{3}{|c|}{ General statistics } & \multicolumn{2}{|c|}{ Females } & \multirow{2}{*}{$\mathbf{P}$} \\
\hline & & \multirow{2}{*}{$\begin{array}{c}\text { Mean } \pm \text { SEM } \\
165.59 \pm 2.78\end{array}$} & \multirow{2}{*}{$\begin{array}{l}\text { Min. } \\
155.29\end{array}$} & \multirow{2}{*}{$\begin{array}{c}\text { Max. } \\
178.92\end{array}$} & \multirow{2}{*}{$\begin{array}{c}\text { Mean } \pm \text { SEM } \\
164.40 \pm 4.89\end{array}$} & \multirow{2}{*}{$\begin{array}{l}\text { Mean } \pm \text { SEM } \\
167.08 \pm 2.28\end{array}$} & \\
\hline 1. & TLS & & & & & & 0.730 \\
\hline 2. & CBL & $163.87 \pm 2.85$ & 156.03 & 180.27 & $162.70 \pm 4.43$ & $165.34 \pm 3.84$ & 0.556 \\
\hline 3. & TLCB & $153.65 \pm 2.34$ & 146.88 & 169.08 & $153.29 \pm 4.00$ & $154.10 \pm 2.43$ & 0.556 \\
\hline 4. & SSL & $113.10 \pm 2.12$ & 104.46 & 125.48 & $111.51 \pm 3.75$ & $115.10 \pm 1.04$ & 0.190 \\
\hline 5. & PPL & $40.02 \pm 0.93$ & 34.40 & 44.49 & $40.86 \pm 1.15$ & $38.97 \pm 1.53$ & 0.556 \\
\hline 6. & NCL & $103.56 \pm 1.52$ & 100.01 & 113.93 & $105.51 \pm 2.41$ & $101.13 \pm 0.80$ & 0.190 \\
\hline 7. & ULVC & $83.71 \pm 1.88$ & 73.97 & 92.27 & $84.01 \pm 2.07$ & $83.33 \pm 3.75$ & 0.905 \\
\hline 8. & MFL & $98.45 \pm 2.19$ & 89.29 & 112.52 & $102.37 \pm 2.66$ & $93.55 \pm 1.56$ & 0.016 \\
\hline 9. & ACBL & $31.92 \pm 2.07$ & 22.97 & 40.71 & $33.32 \pm 3.27$ & $30.17 \pm 2.45$ & 0.556 \\
\hline 10. & FRL & $82.41 \pm 2.91$ & 71.92 & 97.85 & $88.27 \pm 3.09$ & $75.08 \pm 1.58$ & 0.032 \\
\hline 11. & UNCL & $72.83 \pm 3.29$ & 55.76 & 90.14 & $79.14 \pm 3.26$ & $64.94 \pm 3.15$ & 0.016 \\
\hline 12. & FCL & $121.28 \pm 4.94$ & 93.00 & 141.39 & $111.89 \pm 5.02$ & $133.03 \pm 4.68$ & 0.016 \\
\hline 13. & ACIO & $118.75 \pm 1.79$ & 111.49 & 129.16 & $118.72 \pm 2.73$ & $118.78 \pm 2.62$ & 0.730 \\
\hline 14. & GLLB & $21.09 \pm 0.79$ & 16.51 & 23.53 & $19.80 \pm 1.11$ & $22.71 \pm 0.38$ & 0.05 \\
\hline 15. & GLNB & $49.95 \pm 2.93$ & 36.75 & 59.93 & $46.27 \pm 4.49$ & $54.55 \pm 2.26$ & 0.286 \\
\hline 16. & EOPL & $80.65 \pm 1.55$ & 73.64 & 87.64 & $79.35 \pm 2.30$ & $82.28 \pm 1.99$ & 0.556 \\
\hline 17. & DOCI & $118.53 \pm 1.89$ & 112.62 & 130.91 & $120.05 \pm 3.20$ & $116.63 \pm 1.48$ & 0.730 \\
\hline 18. & DTL & $94.40 \pm 1.95$ & 88.18 & 105.11 & $96.98 \pm 2.93$ & $91.18 \pm 1.51$ & 0.111 \\
\hline 19. & OPL & $77.97 \pm 3.60$ & 64.86 & 94.76 & $85.47 \pm 3.72$ & $68.60 \pm 1.34$ & 0.016 \\
\hline 20. & LLPM & $50.02 \pm 1.42$ & 43.98 & 57.90 & $48.08 \pm 1.48$ & $52.45 \pm 2.22$ & 0.190 \\
\hline 21. & LMTR & $53.22 \pm 1.28$ & 47.67 & 59.51 & $51.78 \pm 1.70$ & $55.02 \pm 1.73$ & 0.413 \\
\hline 22. & LUMR & $30.15 \pm 1.42$ & 24.39 & 36.17 & $27.83 \pm 1.70$ & $33.04 \pm 1.52$ & 0.05 \\
\hline 23. & LUPR & $22.32 \pm 0.69$ & 18.70 & 25.06 & $23.44 \pm 0.60$ & $20.91 \pm 1.03$ & 0.111 \\
\hline 24. & GIWO & $33.46 \pm 0.32$ & 32.19 & 34.86 & $33.16 \pm 0.52$ & $33.83 \pm 0.28$ & 0.413 \\
\hline 25. & GIHO & $34.88 \pm 0.57$ & 32.59 & 37.23 & $34.10 \pm 0.54$ & $35.84 \pm 0.94$ & 0.111 \\
\hline 26. & GMB & $51.95 \pm 1.04$ & 46.46 & 55.96 & $52.76 \pm 1.76$ & $50.94 \pm 0.83$ & 0.413 \\
\hline 27. & GBOC & $33.92 \pm 1.57$ & 27.31 & 40.84 & $34.13 \pm 2.31$ & $33.65 \pm 2.41$ & 1.000 \\
\hline 28. & GBPP & $48.28 \pm 1.67$ & 39.79 & 54.17 & $48.12 \pm 2.83$ & $48.47 \pm 1.83$ & 1.000 \\
\hline 29. & GBFM & $16.28 \pm 0.36$ & 14.57 & 18.35 & $15.87 \pm 0.41$ & $16.80 \pm 0.57$ & 0.190 \\
\hline 30. & HFM & $15.03 \pm 0.32$ & 13.44 & 16.27 & $15.53 \pm 0.27$ & $14.42 \pm 0.52$ & 0.190 \\
\hline 31. & LBP & $35.74 \pm 0.96$ & 30.88 & 40.14 & $36.42 \pm 1.52$ & $34.89 \pm 1.11$ & 0.413 \\
\hline 32. & GBLH & $55.75 \pm 2.25$ & 49.95 & 65.15 & - & $55.75 \pm 3.37$ & - \\
\hline 33. & GNCB & $56.84 \pm 0.84$ & 52.98 & 60.25 & $55.21 \pm 0.75$ & $58.88 \pm 0.89$ & 0.032 \\
\hline 34. & GFB & $69.16 \pm 2.24$ & 57.12 & 75.93 & $68.95 \pm 3.29$ & $69.44 \pm 3.47$ & 0.905 \\
\hline 35. & LBO & $82.07 \pm 1.11$ & 78.56 & 88.03 & $80.80 \pm 1.83$ & $83.66 \pm 0.55$ & 0.190 \\
\hline 36. & FCB & $56.47 \pm 1.12$ & 51.96 & 63.40 & $56.79 \pm 1.94$ & $56.09 \pm 1.10$ & 1.000 \\
\hline & GBAN & $24.60 \pm 1.19$ & 19.32 & 28.82 & $23.30 \pm 1.58$ & $26.24 \pm 1.64$ & 0.286 \\
\hline & GBAP & $28.96 \pm 1.17$ & 21.45 & 33.91 & $27.84 \pm 1.64$ & $30.35 \pm 1.61$ & 0.730 \\
\hline & GPB & $47.39 \pm 0.87$ & 44.46 & 51.77 & $47.39 \pm 1.24$ & $47.40 \pm 1.40$ & 0.905 \\
\hline
\end{tabular}

S.E.: Standard error of mean.

Table 4. The mean and standard deviations of the skull volume and surface area.

\begin{tabular}{lcccccc}
\hline \multirow{2}{*}{ Parameter } & \multicolumn{3}{c}{ General statistics } & \multicolumn{1}{c}{ Females } & Males & \multirow{2}{*}{ P } \\
\cline { 2 - 6 } & Mean \pm SEM & Min. & Max. & Mean \pm SEM & Mean \pm SEM & \\
\hline Volume $\left(\mathrm{cm}^{3}\right)$ & $101.71 \pm 2.31$ & 69.14 & 151.67 & $87.69 \pm 1.09$ & $115.74 \pm 2.43$ & 0.008 \\
Area $\left(\mathrm{cm}^{2}\right)$ & $78.48 \pm 9.80$ & 61.31 & 91.17 & $77.34 \pm 1.18$ & $79.62 \pm 8.56$ & NS \\
\hline
\end{tabular}

SEM: Standard error of mean, NS: Non significant. 
Table 5. The mean and standard deviations of the craniofacial indices.

\begin{tabular}{|c|c|c|c|c|c|c|}
\hline \multirow{2}{*}{ Index } & \multicolumn{3}{|c|}{ General statistics } & \multirow{2}{*}{$\begin{array}{c}\text { Females } \\
\text { Mean } \pm \text { SEM }\end{array}$} & \multirow{2}{*}{$\begin{array}{c}\text { Males } \\
\text { Mean } \pm \text { SEM }\end{array}$} & \multirow{2}{*}{$\mathbf{P}$} \\
\hline & Mean \pm SEM & Min. & Max. & & & \\
\hline Skull & $41.86 \pm 1.50$ & 32.94 & 46.36 & $42.12 \pm 2.45$ & $41.54 \pm 1.86$ & 0.730 \\
\hline Cranial & $58.01 \pm 1.74$ & 49.87 & 65.60 & $54.03 \pm 1.08$ & $62.98 \pm 1.18$ & 0.016 \\
\hline For. magnum & $92.84 \pm 3.35$ & 73.24 & 108.92 & $98.16 \pm 3.53$ & $86.18 \pm 4.49$ & 0.111 \\
\hline Orbital & $96.09 \pm 1.49$ & 90.59 & 104.02 & $97.27 \pm 1.12$ & $94.61 \pm 3.15$ & 0.286 \\
\hline Facial & $47.45 \pm 2.92$ & 37.97 & 68.17 & $51.51 \pm 4.36$ & $42.36 \pm 2.04$ & 0.063 \\
\hline Nasal & $50.30 \pm 3.17$ & 38.44 & 64.27 & $51.67 \pm 4.70$ & $48.60 \pm 4.67$ & 0.556 \\
\hline
\end{tabular}

SEM: Standard error of mean.

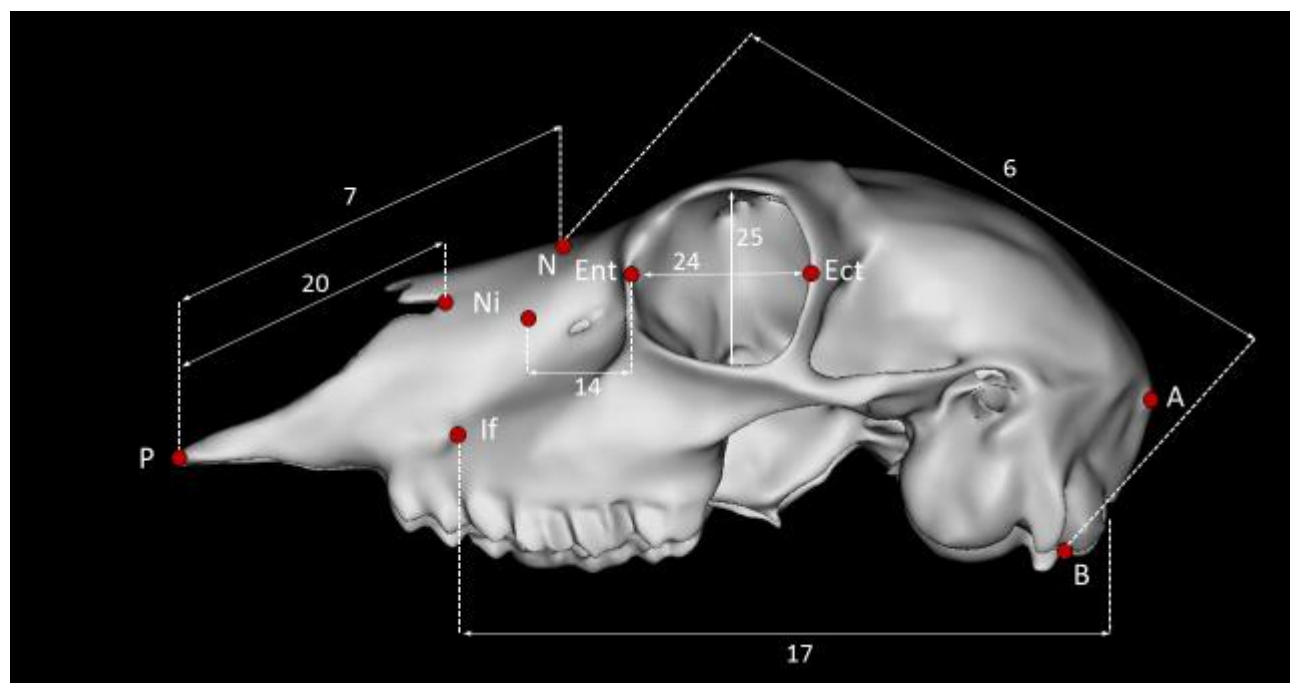

Figure 1. Measurement points of craniometric variables in the gazelle skull (lateral view).

A: Akrokranion, Br: Bregma, Ect: Ectorbitale, Ent: Entorbitale, Ni: Nasointermaxillare If: Infraorbitale, N: Nasion, P: Prosthion, 6: Neurocranium length (NCL), 7: Upper length of the viscerocranium (ULVC), 14: Greatest length of the lacrimal bone (GLLB), 17: Distance between the caudal border of one occipital condyle and the infraorbitale of the same side (DOCI), 20: Lateral length of the premaxilla (LLPM), 24: Greatest inner width of the orbit (GIWO), 25: Greatest inner height of the orbit (GIHO).

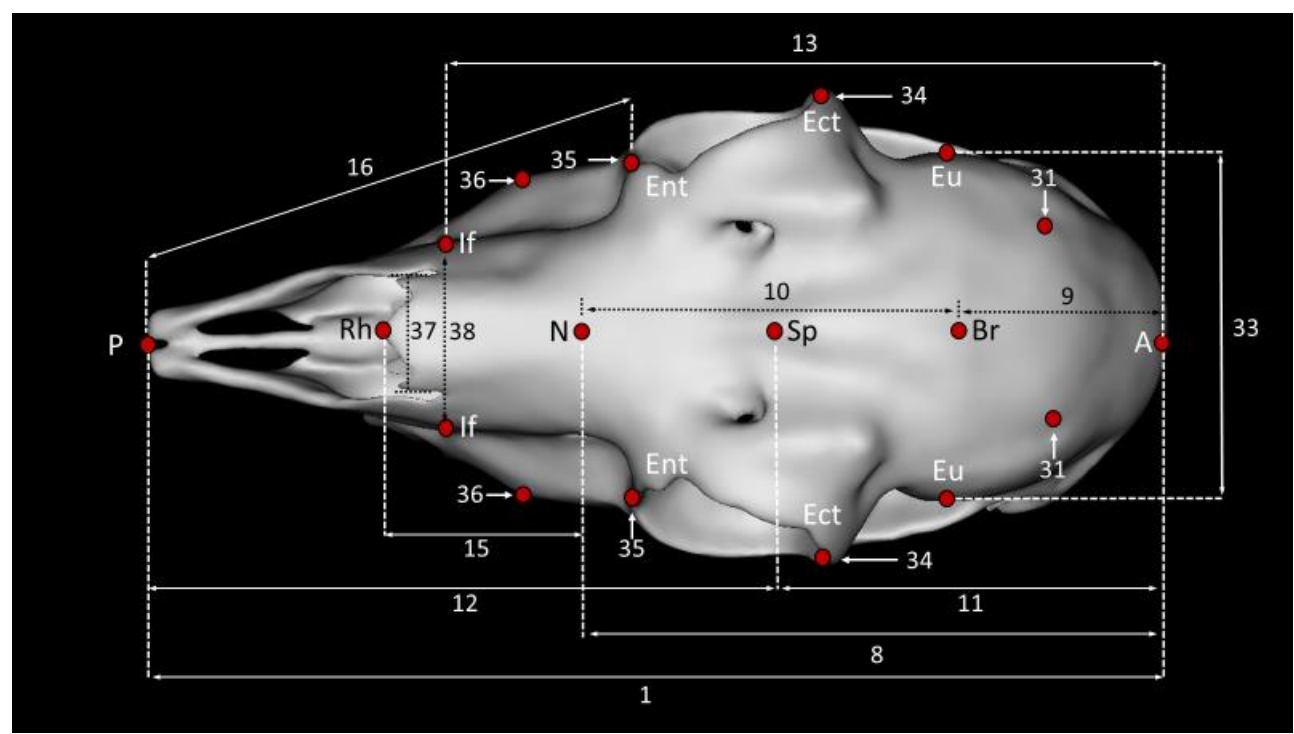

Figure 2. Measurement points of craniometric variables in the gazelle skull (dorsal view).

A: Akrokranion, Br: Bregma, Ect: Ectorbitale, Ent: Entorbitale, Eu: Euryon, If: Infraorbitale, N: Nasion, P: Prosthion, Rh: Rhinion, Sp: Supraorbitale, 1: Total length of the skull (TLS), 8: Median frontal length (MFL), 9: Akrokranion-bregma length (ACBL), 10: Frontal length (FRL), 11: Upper neurocranium length (UNCL), 12: Facial length (FCL), 13: Akrokranion-infraorbitale length (ACIO), 15: Greatest length of the nasal bone (GLNB), 16: Entorbitale-prosthion length (EOPL), 31: Least breadth of parietal (LBP), 33: Greatest neurocranium breadth (GNCB), 34: Greatest frontal breadth (GFB), 35: Least breadth between the orbits (LBO), 36: Facial breadth (FCB), 37: Greatest breadth across the nasal bones (GBAN), 38: Greatest breadth across the premaxilla (GBAP). 


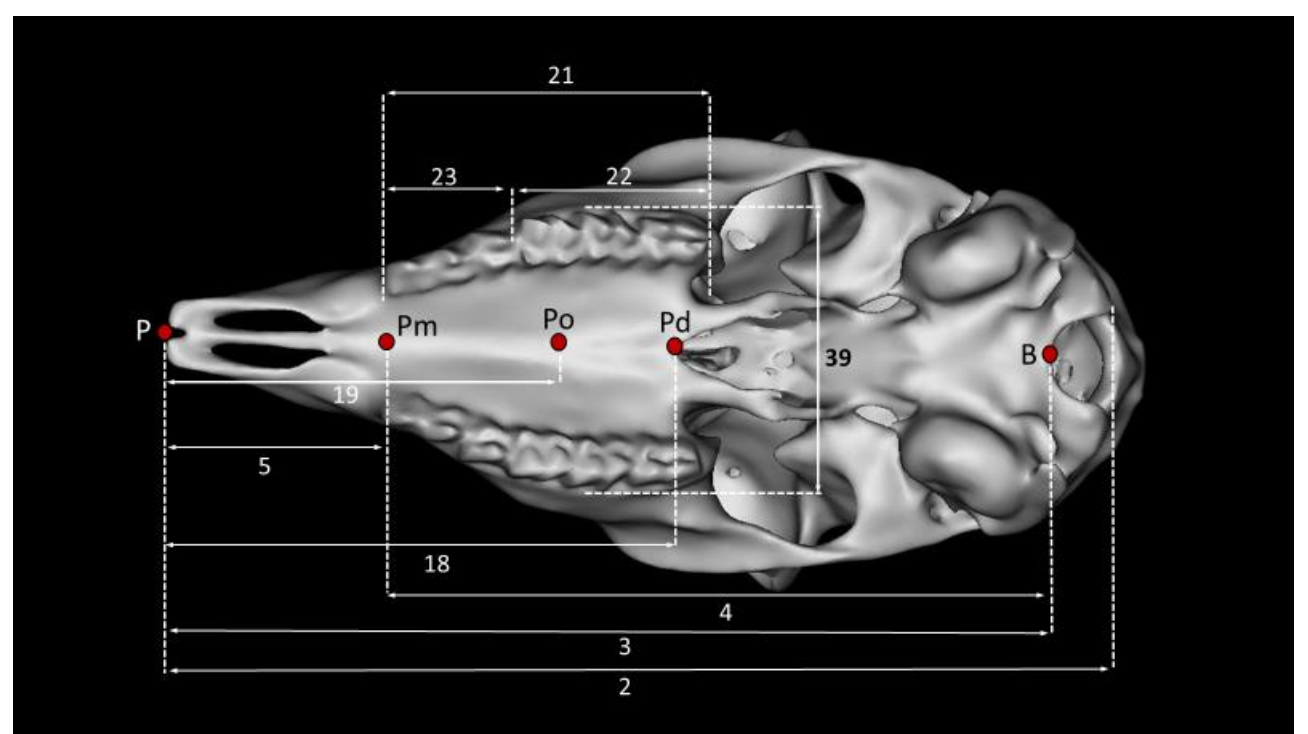

Figure 3. Measurement points of craniometric variables in the gazelle skull (ventral view).

B: Basion, P: Prosthion, Pd: Postdentale, Pm: Premolare, Po: Palatinoorale, 2: Condylobasal length (CBL), 3: Total length of the cranial base (TLCB), 4: Short skull length (SSL), 5: Premolare-prosthion length (PPL), 18: Dental length (DTL), 19: Oral palatal length (OPL), 21: Length of the maxillary tooth row (LMTR), 22: Length of the upper molar row (LUMR), 23: Length of the upper premolar row (LUPR), 39: Greatest palatal breadth (GPB).

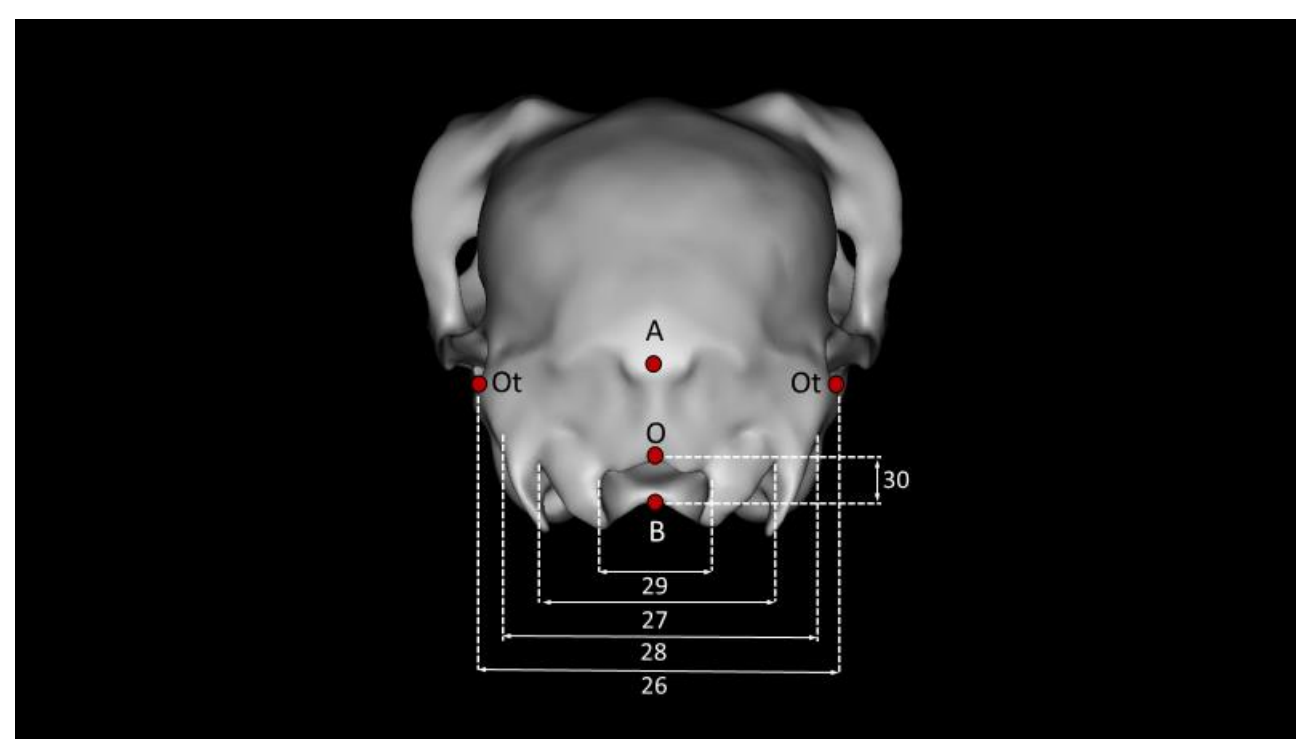

Figure 4. Measurement points of craniometric variables in the gazelle skull (occipital view).

A: Akrokranion, B: Basion, O: Opisthion, Ot: Otion, 26: Greatest mastoid breadth (GMB), 27: Greatest breadth of the occipital condyles (GBOC), 28: Greatest breadth at the bases of the paracondylar processes (GBBPP), 29: Greatest breadth of the foramen magnum (GBFM), 30: Heigth of the foramen magnum (HFM).

\section{Discussion and Conclusion}

Craniometric analyses have been used to differentiate species within the same genus and to investigate morphological variations within species. Several reports on craniometric measurements using traditional methods (the help of scale and digital calipers) in gazelles are found in the literature $(7,31)$. This study presents for the first time morphometric and volumetric measurements of the skull in gazelles by using threedimensional CT images. Due to the lack of data on CT based measurements in gazelles, data obtained from different gazelle species by traditional methods or data obtained from sheep and goats were used for comparison.

Due to remarkable morphological variations both among gazelle species and among individuals within the same species, assigning an individual to a certain species might be difficult (28). Therefore, more data are required for assessing the morphometric variation within the species. On the other hand, craniofacial index parameters are also necessary for examining craniofacial deformities and investigating brain development (13). 
Zhu (31) has reported the skull index by examining the craniometrics values of Tibetan gazelle as $43.22 \pm 0.44$ $\mathrm{mm}$, cranial index as $58.37 \pm 0.80 \mathrm{~mm}$ and facial index as $116.37 \pm 1.24 \mathrm{~mm}$. The facial index value found in the present study $(47.45 \pm 2.92 \mathrm{~mm})$ was lower than that reported by Zhu (31). The difference might be attributed to the use of different species and methods.

The orbital region plays an important role in craniofacial measurements, forensic processes and differential diagnosis (8). A tubular shape of orbita was observed in gazelles in the present study. The orbita can have a different shapes depending on the species and the breed of the same species. It has been reported that orbita has the shape of almond in Spanish Xisqueta sheep (24) while it has an oval shape in Mehreban sheep of Iran (14). Even a bilateral variation between the right and left orbitas in Kagani goats (Capra hircus) has been reported (12). In accordance with the present study Leslie (18), has reported a similar shape of orbita in Procapra picticaudata. Similar to our findings Parés-Casanova et al. (24) have reported an orbital index value of $97.27 \pm 1.12 \mathrm{~mm}$ and $94.61 \pm 3.15$ $\mathrm{mm}$ in female and male Spanish Xisqueta sheep respectively.

Mean breadth and height of foramen magnum in the gazelles were measured as $16.28 \pm 0.36 \mathrm{~mm}$ and $15.03 \pm 0.32 \mathrm{~mm}$ respectively and foramen magnum index was $92.84 \pm 3.35 \mathrm{~mm}$. These values were lower than those found in sheep (21) and goats (15). Similar to those reported in sheep and goats $(15,21)$ the horizontal diameter of the foramen magnum was longer than its vertical diameter in the gazelles.

Sexual dimorphism is common among mammals and has been an important evolutionary factor in social ecology (5). The effect of sex on bone morphology has been intensively studied in humans (2) goats (6) and wild sheep (11). However, the limited number of studies on the effect of sex on bone morphology in gazelles have been conducted (30). In the present study, significant differences between males and females were observed for MFL (median frontal length), FRL (frontal length), UNCL (upper neurocranium length), GLLB (greatest length of the lacrimal bone), OPL (oral palatal length), LUMR (length of the upper molar row) and GNCB (greatest neurocranium breadth).

Conventional radiological methods used for assessing the skull volume employ two-dimensional measurements. Computer tomography based methods present a more precise and noninvasive way for estimating in vivo skull volume (3). Mean skull volumes in females and males were detected as $87.69 \pm 1.09 \mathrm{~cm}^{3}$ and $115.74 \pm 2.43 \mathrm{~cm}^{3}$, respectively. In contrast to the findings in this study, Chanpanitkitchote et al. (4) have reported a skull volume of Grant's gazelles (Nanger granti) as $1016 \pm 11 \mathrm{~cm}^{3}$. The differences in the morphometric values between the species have been attributed to inclusion or exclusion of mandible, horn status of the animal, measurement methods used or live weight of the animal.

In conclusion, new technologies like CT presents opportunities for obtaining comprehensive data on skull morphometry in animals. This study was the first reporting the use of CT for morphometric analysis of the skull in goitered gazelle (Gazella subgutturosa). The data obtained in this study will be useful for not only the evaluation of CT images from facial, cranial of dental deformities but also for determining the sex based on bone morphometry and for taxonomical studies. However further studies are necessary for comparing the data obtained from 3D modeling and actual measurements on skulls by including larger sample size.

\section{Financial Support}

This study was supported by Scientific Research Center of Harran University (Project number: 18004).

\section{Conflict of Interest}

The authors declared that there is no conflict of interest.

\section{References}

1. Bärmann EV, Wronski T, Lerp H, et al (2013): Morphometric and genetic framework for Gazella. Zoo J Linnean Soc, 169, 673-696.

2. Best KC, Garvin HM, Cabo LL (2018): An investigation into the relationship between human cranial and pelvic sexual dimorphism. J Forensic Sci, 63, 990-1000.

3. Breiman RS, Beck JW, Korobkin M, et al (1982): Volume determinations using computed tomography. AJR Am J Roentgenol, 138, 329-333.

4. Chanpanitkitchote $P$, Tangphokhanon $W$, Nomsiri R, et al (2015): Ratio of cranial and skull volumes in 25 mammalian species. Vet Integr Sci, 13, 165-177.

5. Christiansen P, Harris JM (2012): Variation in craniomandibular morphology and sexual dimorphism in Pantherines and the Sabercat Smilodon fatalis. PLoS One, 7, e48352.

6. Fandos P, Vigal CR (1993): Sexual dimorphism in size of the skull of Spanish ibex Capra pyrenaica. Acta Theriol, 33, 103-111.

7. Groves CP (1983): Notes on the gazelles IV: the Arabian gazelles collected by Hemprich and Ehrenberg. Z Saugetierkd, 48, 371-381.

8. Hasan HA (2017): Three dimensional computed tomography morphometric analysis of the orbit in Iraqi population. Int Med J, 24, 147-149.

9. Hayatgheib D, Karami M, Farahmand H, et al (2011): Morphological study and comparison of western and eastern goitered gazelle (Gazella subgutturosa: Guldenstaedt, 1780) populations in Iran. Int J Environ Res, 5, 225-232.

10. Ince NG, Demircioglu I, Yılmaz B, et al (2018): Martılarda (Laridae spp.) cranium'un üç boyutlu modellemesi. Harran Univ Vet Fak Derg, 7, 98-101. 
11. Jaslow JR (1989): Sexual dimorphism of cranial suture complexity in wild sheep (Ovis orientalis). Zoo J Linnean Soc, 95, 273-284.

12. Kamal S (2006): Morphological and craniometrical studies on the skull of Kagani goat (Capra hircus) of Jammu region. Int J Morphol, 24, 449-455.

13. Kanchan T, Krishan K, Gupta A, et al (2014): A study of cranial variations based on craniometric indices in a South Indian population. J Craniofac Surg, 25, 1645-1649.

14. Karimi I, Onar V, Pazvan G, et al (2011): The cranial morphometric and morphologic characteristics of Mehraban sheep in Western Iran. Glob Vet, 6, 111-117.

15. Kataba A (2010): Biometric and morphologic characteristics of the skull of the Gwembe Valley Dwarf Goat (Capra Hircus) breed of Zambia. MSc, University of Zambia, Lusaka, Zambia.

16. Kranioti EF (2019): Radiometry versus osteometry in sex assessment: a study of the Cretan radius. Aust J Forensic Sci, 51, 135-148.

17. Krupa P, Krsek P, Cernochova P, et al (2004): 3D real modelling and CT biomodels application in facial surgery. In: Neuroradiology, Springer, Berlin.

18. Leslie DM (2010): Procapra picticaudata (Artiodactyla: Bovidae). Mamm Species, 42, 138-148.

19. Mallon DP, Kingswood SC (2001): Antelopes. Part 4: North Africa, the Middle East, and Asia. Global Survey and Regional Action Plans. SSC Antelope Specialist Group. IUCN, Gland, Switzerland and Cambridge, UK.

20. Nomina Anatomica Veterinaria (2017): International committee on veterinary gross anatomical nomenclature
(ICVGAN), Published by the Editorial Committee, Hannover.

21. Özcan S, Aksoy G, Kürtül İ, et al (2010): A comparative morphometric study on the skull of the Tuj and Morkaraman sheep. Kafkas Univ Vet Fak Derg, 16, 111-114.

22. Özkurt A (2002): Üç boyutlu örneksel veriden yüzey modeli üretimi. DEUFMD, 4, 27-36.

23. Páral V, Tichý F, Fabiś M (2004): Functional structure of metapodial bones in Cattle. Acta Vet Brno, 73, 413-420.

24. Parés I, Casanova PM, Kamal S, et al (2010): On biometrical aspects of the cephalic anatomy of Xisqueta sheep (Catalunya, Spain). Int J Morpol, 28, 347-351.

25. Parés-Casanova PM (2014): Osteometric study of the Rasquera White goat. J Appl Anim Res, 42, 177-185.

26. Tecirlioğlu S (1983): Sirtlan ve köpeğin iskelet kemikleri üzerinde makro-Anatomik araştırmalar. Ankara Univ Vet Fak Derg, 30, 149-166.

27. Teo EC, Holsgrove T, Haiblikova S (2017): $3 D$ Morphometric analysis of human vertebrae C3-T3 using CT images reconstruction. J Spine, 6, 391.

28. Thouless CR, Al Bassri KA (1991): Taxonomic status of the Farasan island gazelle. J Zool Lond, 223, 151-159.

29. Von Den Driesch A (1976): A guide to the measurement of animal bones from archaeological sites. Peabody Museum Bulletin 1. Cambridge, MA, Harvard University.

30. Wronski T, Sandouka M, Plath M, et al (2010): Differences in sexual dimorphism among four gazelle taxa (Gazella spp.) in the Middle East. Animal Biol, 60, 395-412.

31. Zhu L. (2012): Craniometrical studies on the skull of Tibetan Gazelle (Procapra Picticaudata). Int J Morphol, 30, 196-198. 